ISSN 1392-3196

Zemdirbyste-Agriculture, vol. 100, No. 1 (2013), p. 33-38

UDK 631.431.73:633.2.033 / DOI 10.13080/z-a.2013.100.005

\title{
Soil compaction in a Cambisol under grassland in Estonia
}

\author{
Kadri KREBSTEIN ${ }^{1}$, Katrin von JANOWSKY ${ }^{2}$, Endla REINTAM ${ }^{1}$, Rainer HORN ${ }^{3}$, \\ Janar LEEDUKS ${ }^{1}$, Jaan KUHT ${ }^{1}$ \\ ${ }^{1}$ Institute of Agricultural and Environmental Sciences, Estonian University of Life Sciences \\ Kreutzwaldi 1A, 51014 Tartu, Estonia \\ E-mail: kadri.krebstein@emu.ee \\ ${ }^{2}$ Institute for Hygiene and Environment \\ Marckmannstraße 129B, 20539 Hamburg, Germany \\ ${ }^{3}$ Christian Albrecht University of Kiel \\ Hermann-Rodewald 2, 24118 Kiel, Germany
}

\begin{abstract}
In soil compaction research, more attention has been given to arable land than to grasslands. Our objective was to investigate the effect of agricultural machinery on the physical and mechanical properties of soil under intensively cut lucerne (Medicago sativa L.). A field experiment was conducted in South Estonia, near the city of Tartu, on a second-year mainly lucerne field on a sandy loam Calcaric Cambisol (CMca). After the third silage cut, soil properties were measured in the wheel traffic lanes (compacted) and between the traffic lanes (uncompacted). Our results showed that wheeling significantly affected the soil structure. Soil compaction increased soil bulk density (BD) by $0.19 \mathrm{~g} \mathrm{~cm}^{-3}$ at $5 \mathrm{~cm}$ depth and by $0.14 \mathrm{~g} \mathrm{~cm}^{-3}$ at $10 \mathrm{~cm}$ depth. Soil compaction also affected the pore distribution: soil air capacity (AC) in compacted soil at 5 and $10 \mathrm{~cm}$ depth was significantly (more than 10 vol. \%) lower than in uncompacted soil, and plant-available water (PAW) increased at 10 and $20 \mathrm{~cm}$ depth but decreased at $5 \mathrm{~cm}$ depth. Air conductivity $\left(\mathrm{k}_{\mathrm{a}}\right)$ and saturated hydraulic conductivity $\left(\mathrm{k}_{\mathrm{s}}\right)$ decreased significantly at 5 and $10 \mathrm{~cm}$ depth. Soil precompression stress $\left(\mathrm{P}_{c}\right)$ was lower in the uncompacted area: soil compaction increased $\mathrm{P}_{c}$ by $60 \mathrm{kPa}$ at $5 \mathrm{~cm}$ depth and by $30 \mathrm{kPa}$ at $10 \mathrm{~cm}$ depth. Cohesion was greater in the compacted area than in the uncompacted area (mean difference $10 \mathrm{kPa}$ ). This study clearly indicates that soil compaction is a problem for grasslands.
\end{abstract}

Key words: air conductivity, bulk density, cohesion, grassland, hydraulic conductivity, precompression stress, soil compaction.

\section{Introduction}

Soil compaction is a worldwide environmental problem in arable systems. According to Oldeman et al. (1991), over 68 Mha of global land in agricultural use is affected by soil compaction, 33 Mha of which is in Europe. In Estonia in 2010, according to Statistics Estonia (Statistikaamet, 2012), the total area used for agricultural production was 948826 ha, of which $20 \%$ is permanent grassland. Grasslands are often located in areas in which conventional cultivation is impossible. Hydromorphic or semi-hydromorphic soils are often used as grassland instead of arable land in Estonia.

The focus on cultivated land in soil compaction research is based on the belief that grassland soils are stable because of the perennial plant cover and root reinforcement. The perennial nature and root structure of grassland vegetation are thought to improve the stability and bearing capacity of its soil (Cofie et al., 2000) and reduce the stress transmitted to greater depths (Stahl et al., 2009). Trükmann (2011) showed that plant roots increased soil stability on grassland: shear strength at the densely rooted $5 \mathrm{~cm}$ depth was significantly higher than that at the less densely rooted $20 \mathrm{~cm}$ depth. The strength of rooted soil depends on the individual strengths of the

soil and the roots as well as on the interface strength between the soil and the roots.

Despite the stability provided by the vegetation, soil compaction can occur in grasslands. Higher wheel loads are causing an increasing severity of soil compaction. Machinery power and the weight of tractors and harvesting machines have increased, affecting grasslands and arable lands. Stahl et al. (2009) noted that machines typically used for grassland management have wheel loads of more than $5 \mathrm{Mg}$. Furthermore, the production of perennial forage crops results in a high level of traffic (fertiliser and slurry spreading, rolling, harvesting and transport), particularly during crop harvesting operations (Jorajuria, Draghi, 1997). Frost (1988) showed that in grasslands used for silage, the entire area of a field is passed over by tractor wheels up to nine times each year. Frame and Merrilees (1996) noted that the production of high-quality fodder requires an early first cut, which cannot always be conducted under ideal weather and soil conditions. If the cut is conducted while the soil remains wet, wheeling takes place on weak soil.

The changes in grassland soil properties due to soil compaction depend on several exogenous factors. 
One set of factors includes machine parameters, such as wheel load, inflation pressure, loading time and wheeling frequency (Horn et al., 2003). Another important factor is soil structural stability, which depends on soil texture, organic matter content and aggregation (Horn, Rostek, 2000). If external soil stress is lower than internal soil strength, an elastic deformation (recoverable) occurs, but if internal soil strength is exceeded by external stresses, the soil reacts with plastic deformation (irreversible) (Horn et al., 2003). Plastic soil compression decreases the soil volume and changes the pore size distribution by reducing the volume of coarse pores and increasing the fraction of smaller pores (Pagliai et al., 2003). These compression processes are responsible for many adverse changes in soil functions, including low hydraulic conductivity and aeration (Lipiec, Hatano, 2003). The direct effects of soil compaction on plant growth are reduced root growth and function and reduced supply of oxygen and nutrients to roots (Lipiec, Hatano, 2003). All of these factors can constrain plant growth and lead to decreased production of perennial forages. Jorajuria and Draghi (1997) found a yield decrease of 52-76\% for grassland vegetation in the traffic lane. Glab (2008) showed a decrease of up to $27 \%$ in the aboveground dry weight of lucerne, and Reintam et al. (2006) showed a decrease of up to $50 \%$ in the shoot dry weight of barley and narrow-leafed lupine. In the same study they also found that yellow lupine shoot mass decreased by $10 \%$ on the plots wheeled 6 times (total tractor weight $4.8 \mathrm{Mg}$ ) on a Stagnic Luvisol (LVst) sandy loam.

There are insufficient experimental data on the effect of compaction on soil properties in grasslands. The aim of this investigation was to study the effect of agricultural machinery on the physical and mechanical properties of soil under a field consisting primarily of lucerne, cut for silage.

\section{Materials and methods}

Site and soil of the experiment. The 2007 pilot study investigated changes in the soil properties of an intensively used second-year lucerne (Medicago sativa L.) field in Vorbuse, Estonia (latitude $58^{\circ} 25^{\prime} \mathrm{N}$, longitude $26^{\circ} 39^{\prime} \mathrm{E}$ ), near the city of Tartu. The climate is humidtemperate with a mean annual precipitation of $695.2 \mathrm{~mm}$ and average temperature of $6.7^{\circ} \mathrm{C}$ in 2007 . The soil in the experimental area was a Calcaric Cambisol (CMca) (IUSS Working Group WRB, 2007). The texture was sandy loam containing sand $(0.063-2 \mathrm{~mm}) 58 \%$, silt $(0.002-0.063 \mathrm{~mm}) 31 \%$ and clay $(<0.002 \mathrm{~mm}) 11 \%$. The average soil characteristics at $0-30 \mathrm{~cm}$ depth were $\mathrm{pH}_{\mathrm{KCl}}$ $6.4, \mathrm{C}_{\text {org }} 12 \mathrm{~g} \mathrm{~kg}^{-1}$, sand $58 \%$, silt $31 \%$ and clay $11 \%$. No fertilisers were used in this trial.

Characteristics of the trial. Data were collected from the field after the third silage cut of lucerne (Medicago sativa L.) on $24^{\text {th }}$ September 2007 . There were two different levels of soil compaction: compacted (in wheel tracks) and uncompacted (between wheel tracks). Soil compaction was generated using a pick-up machine (total full load: $12 \mathrm{Mg}$ ) with an axle load of $3.5 \mathrm{Mg}$ and calculated soil contact pressure of $258 \mathrm{kPa}$ (O'Sullivan et al., 1999 a). The soil water content at $0-30 \mathrm{~cm}$ depth during soil compaction corresponded to $\mathrm{pF}=1.7$ (ca $30 \%$ ). Undisturbed soil samples were taken with steel cylinders from 5, 10 and $20 \mathrm{~cm}$ depth in September.
Undisturbed soil samples for porosity, bulk density (BD) and saturated hydraulic conductivity $\left(\mathrm{k}_{\mathrm{s}}\right)$ were taken with steel cylinders (cylinder $100 \mathrm{~cm}^{3}$, diameter $5 \mathrm{~cm}$ and height $4 \mathrm{~cm}$ ) from 5, 10 and $20 \mathrm{~cm}$ depth. For BD and soil porosity characteristics we had 36 samples (18 for compacted and 18 for uncompacted area, for each depth $-5,10$ and $20 \mathrm{~cm}, 6$ replications). For $\mathrm{k}_{\mathrm{s}}$ we had 78 samples (39 for compacted and 39 for uncompacted area, for each depth $-5,10$ and $20 \mathrm{~cm}, 13$ replications).

The undisturbed soil samples for shear parameter: precompression stress $\left(\mathrm{P}_{\mathrm{c}}\right)$, air conductivity $\left(\mathrm{k}_{\mathrm{a}}\right)$ and cohesion were taken with a steel cylinder $235.5 \mathrm{~cm}^{3}$ (diameter $10 \mathrm{~cm}$ and height $3 \mathrm{~cm}$ ). For $\mathrm{P}_{\mathrm{c}}$ we had 9 samples (4 for compacted and 5 for uncompacted area). Samples had mostly two replicates, but one replicate for the treatment in compacted soil at 10 and $20 \mathrm{~cm}$ depth and one for uncompacted soil at $20 \mathrm{~cm}$ depth). For $\mathrm{k}_{\mathrm{a}}$ we had 36 samples (18 for compacted and 18 for uncompacted area, for each depth $-5,10$ and $20 \mathrm{~cm} 6$ replications) and for the cohesion 6 samples, with one replication.

Laboratory methods. To obtain the water retention characteristics, undisturbed soil samples were saturated and equilibrated to a matric potential of $-3 \mathrm{kPa}$ on a sand bed. The samples were then equilibrated to matric potentials of $-6,-15,-30$ and $-50 \mathrm{kPa}$ using ceramic plates and to the matric potential of $-1500 \mathrm{kPa}$ using a pressure chamber. We used for pressure -1500 $\mathrm{kPa}$ disturbed soil samples (diameter $2 \mathrm{~cm}$ and height $1 \mathrm{~cm}$ ) and left the samples under the pressure for 30 days. To determine $\mathrm{BD}$ and total porosity, the samples were dried in an oven at $105^{\circ} \mathrm{C}$ for $24 \mathrm{~h}$. Air capacity (AC) was defined as the difference between total porosity and water content at $-6 \mathrm{kPa}$ matric potential. Plant-available water (PAW) was calculated as the difference between volumetric water content at field capacity (matric potential of $-6 \mathrm{kPa}$ ) and wilting point (matric potential of $-1500 \mathrm{kPa}$ ) (Hartge, Horn, 2009). Saturated hydraulic conductivity $\left(\mathrm{k}_{\mathrm{s}}\right)$ was measured using the falling-head method, as described by Hartge and Horn (2009). Air conductivity $\left(\mathrm{k}_{\mathrm{a}}\right), \mathrm{P}_{\mathrm{c}}$ and shear parameter were measured on undisturbed soil samples (predrained to a matric potential of $-6 \mathrm{kPa})$. Air conductivity $\left(\mathrm{k}_{\mathrm{a}}\right)$ was measured before the shear strength. For more details, see Vossbrink and Horn (2004). Precompression stress $\left(\mathrm{P}_{c}\right)$ was determined by a confined multi-step compression device using an odometer. Defined pressures (10, 20, 30, 50, 70, $100,150,300$ and $400 \mathrm{kPa}$ ) were applied stepwise for 10 min each to the soil sample. Plates of sintered metal above and beneath each soil sample ensured free drainage. Shear parameter cohesion was measured in a frame test under consolidated and drained conditions with normal stresses between 40 and $400 \mathrm{kPa}$ for each normal stress level (40, $70,100,200$ and $400 \mathrm{kPa}$ ). Vertical soil deformation and shear resistance were recorded during the shear test at a constant speed of $0.3 \mathrm{~mm} \mathrm{~min}^{-1}$. Parameter cohesion was derived by performing linear regression on shear resistance as a function of normal stress according to the Mohr-Coulomb equation:

$$
\tau=\mathrm{c}+\sigma \cdot \tan \varphi
$$

where $\tau$ is shear strength, $\mathrm{c}-$ cohesion, $\sigma-$ the normal stress, $\varphi$ - angle of internal friction.

The values of soil physical characteristics were classified according to DVWK (1995; 1997) and Bodenkundliche Kartieranleitung (AG Bodenkunde, 2005) described in Table. 
Table. Classification of the values of soil physical characteristics

\begin{tabular}{cccccccc}
\hline & Unit & 1- very low & $2-$ low & $3-$ medium & $4-$ high & $\begin{array}{c}5-\text { very } \\
\text { high }\end{array}$ & \multicolumn{2}{c}{6 - extremely } \\
high
\end{tabular}

$\mathrm{BD}$ - bulk density, AC - air capacity, PAW - plant-available water, $\mathrm{k}_{\mathrm{s}}$ - saturated hydraulic conductivity, $\mathrm{k}_{\mathrm{a}}$ - air conductivity, $\mathrm{P}_{\mathrm{c}}-$ precompression stress

Statistical analysis. Box plots were chosen for graphical visualisation of the results. Each box plot contains information about the median (black line across the box), arithmetic mean (black point in the box), lower and upper hinges (defined as the $25^{\text {th }}$ and $75^{\text {th }}$ percentiles), and outliers (displayed as diamonds). Fisher's LSD post-hoc test was used to compare the differences between values (arithmetic mean). Results were classified as statistically significant when $p<0.05$. Statistical data analyses were performed with the software $R$, version 2.9.1

\section{Results and discussion}

Soil bulk density (BD) and porosity. The measured soil BD values showed a dependency of soil depth (Fig. 1). The BD values in the uncompacted area were lower at $5 \mathrm{~cm}$ of depth (classified as low) than at $20 \mathrm{~cm}$ depth (classified as medium). Soil air capacity (AC) values were higher at $5 \mathrm{~cm}$ of depth than at 10 and $20 \mathrm{~cm}$ of depth (Fig. 2). The mean AC values of the uncompacted area could be classified as high. The plantavailable water (PAW) values showed also dependency of soil depth (Fig. 3). The PAW values at $20 \mathrm{~cm}$ of depth (classified as low) were more than 10 vol. \% lower than PAW values at $5 \mathrm{~cm}$ of depth (classified as high, Table). During wheeling on the lucerne field, soil compression occurred in the wheel tracks. Soil compaction significantly increased soil BD at $5-10 \mathrm{~cm}$ of depth: BD increased by $0.19 \mathrm{~g} \mathrm{~cm}^{-3}$ at $5 \mathrm{~cm}$ of depth and by $0.14 \mathrm{~g} \mathrm{~cm}^{-3}$ at

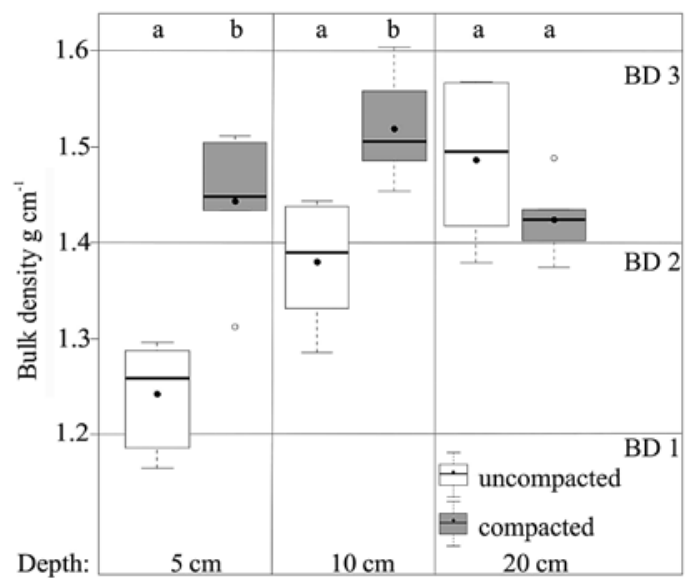

Notes. In each box plot, the median (-) and arithmetic mean $(\bullet)$ values are shown. Different letters indicate significant differences between the soil compaction treatments at one depth $(p<0.05, \mathrm{n}=6)$.

Figure 1. Soil bulk density (BD) depending on soil compaction and soil depth
$10 \mathrm{~cm}$ of depth. Our results obtained in the traffic lanes of pick-up machinery showed that wheeling significantly affected pore size distribution in the grassland soils. The $\mathrm{AC}$ values at 5 and $10 \mathrm{~cm}$ of depth were significantly lower (more than a 10 vol. \% difference) in the compacted area than in the uncompacted area; at $20 \mathrm{~cm}$ of depth, there was a difference, but this difference was not statistically significant. The PAW values increased at $10-20 \mathrm{~cm}$ of depth and decreased at $5 \mathrm{~cm}$ of depth with soil compaction.

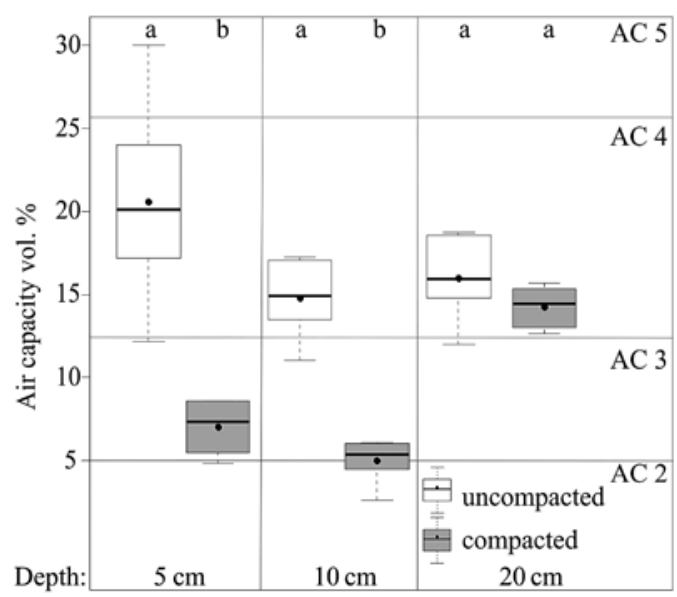

Explanations under Figure 1

Figure 2. Soil air capacity (AC) depending on soil compaction and soil depth

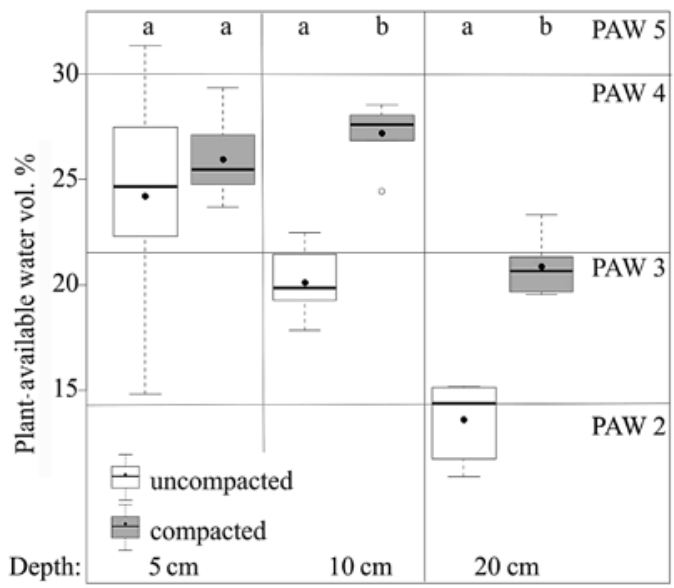

Explanations under Figure 1

Figure 3. Soil plant-available water (PAW) depending on soil compaction and soil depth 
Our results are consistent with those of other studies. Frame and Merrilees (1996) found that for an intensively used silage field (diploid and tetraploid ryegrass swards) on freely drained brown alluvial (by FAO) soil with a sandy loam topsoil and a loamy sand subsoil, wheeling (7 and 15 wheel passes with a tractor mass of $3.2 \mathrm{Mg}$ ) increased dry BD in the compacted area by approximately $0.13 \mathrm{~g} \mathrm{~cm}^{-3}$ compared with the control area. The air-filled porosities of wheeled treatments were also reduced by $4.2 \%$ compared with the control treatments. Reintam et al. (2009) noted that repeated passes with even a low weight tractor (total weight of $4.8 \mathrm{Mg}$ with tyre inflation pressure of $150 \mathrm{kPa}$ ) can induce subsoil compaction and a decrease in plant productivity for spring barley on a Stagnic Luvisol ( $L V s t$ ) of sandy loam. In the same study, BD increased in soil passed over six times by $0.15 \mathrm{Mg} \mathrm{m}^{-3}$ compared to uncompacted soil. Glab (2008) found a BD increase of approximately $0.14 \mathrm{~g} \mathrm{~cm}^{-3}$ at $0-30 \mathrm{~cm}$ depth after six passes (tractor contact area approximately $125 \mathrm{kPa}$ ) over a lucerne field on a Mollic Fluvisol (FLmo) of silty loam. Hammel (1993) found a significant reduction of soil $\mathrm{AC}$ at $5 \mathrm{~cm}$ of depth in the wheel tracks on grassland. Douglas and Crawford (1998) found an increase in BD and a decrease in macropores under different grassland management intensities. Our results showed that there was an increase in PAW in the wheel tracks. This increase indicates that with the decline in macroporosity (pores larger than $50 \mu \mathrm{m}$ diameter), the volume of pores with a diameter of $0.2-50 \mu \mathrm{m}$ increased. This is also confirmed by results in the literature. Koppi et al. (1992) attributed the reduction of $\mathrm{AC}$ to the increase of smaller pores in the grassland soils. The volume of soil macropores with a diameter of $>195 \mu \mathrm{m}$ was significantly larger in the absence of traffic than after conventional traffic. Similarly, SchäferLandefeld et al. (2004) demonstrated that the volume of pores with a diameter of smaller than $30 \mu \mathrm{m}$ increased on conventionally managed fields.

Saturated hydraulic conductivity (k) and air conductivity ( $\boldsymbol{k}_{a}$ ). Our data showed that $\mathrm{k}_{\mathrm{a}}$ and $\mathrm{k}_{\mathrm{s}}$ in the uncompacted area at $5 \mathrm{~cm}$ depth were higher ( $\mathrm{k}$ extremely high, $\mathrm{k}_{\mathrm{a}}$ very high) than at 10 and $20 \mathrm{~cm}$ depth, whereas there was no statistically significant difference between the values at 10 and $20 \mathrm{~cm}$ depth (Figs 4 and 5).

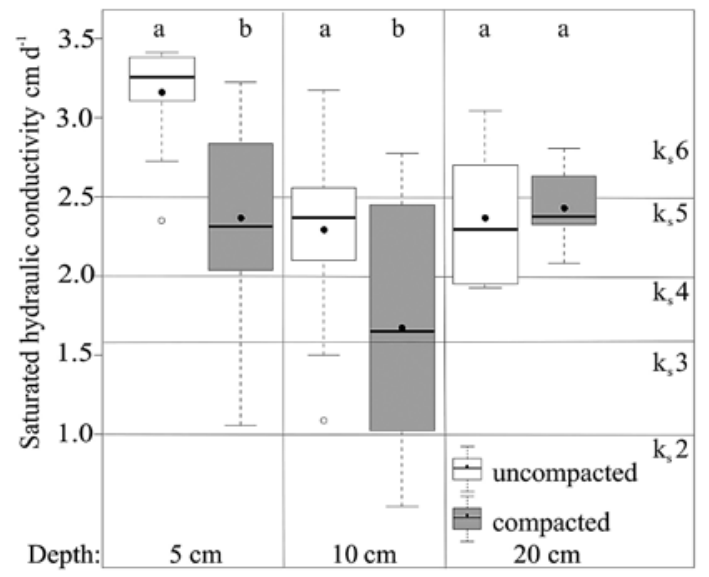

Notes. In each box plot, the median (-) and arithmetic mean $(\bullet)$ values are presented. Different letters indicate significant differences between the soil compaction treatments at one depth $(p<0.05, \mathrm{n}=13)$.

Figure 4. Soil saturated hydraulic conductivity $\left(\mathrm{k}_{\mathrm{s}}\right)$ depending on soil compaction and soil depth

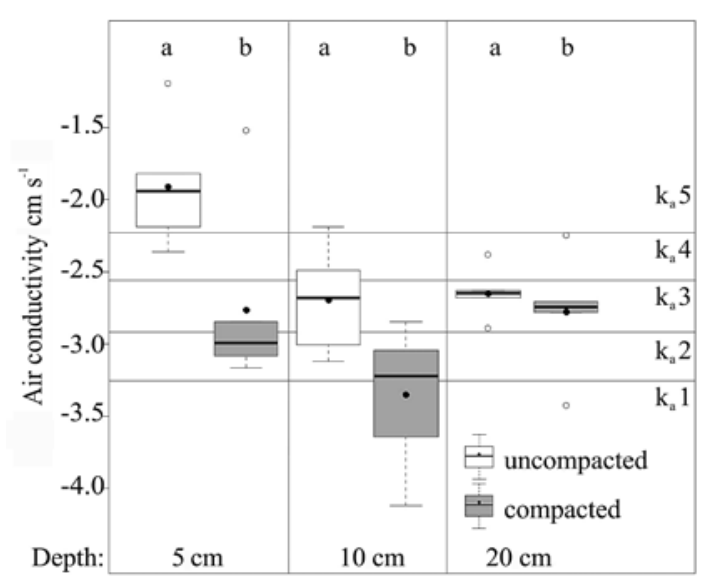

Explanations under Figure 1

Figure 5. Soil air conductivity $\left(\mathrm{k}_{\mathrm{a}}\right)$ depending on soil compaction and soil depth

The decrease in $\mathrm{k}_{\mathrm{a}}$ and $\mathrm{k}_{\mathrm{s}}$ due to soil compaction was statistically significant at 5 and $10 \mathrm{~cm}$ depth. Although the $\mathrm{k}_{\mathrm{s}}$ values decreased, the data of the compacted area could be classified as very high (5 and $20 \mathrm{~cm}$ depth) and high (10 cm depth, arithmetic mean). The decrease in $\mathrm{k}$ was from very high to medium at $5 \mathrm{~cm}$ depth and from medium to very low at $10 \mathrm{~cm}$ (difference in arithmetic mean).

Because of the decreased soil volume and associated decrease in macroporosity, the saturated water and air conductivity were reduced in the compacted area. Many authors have shown, with the help of different soil compaction experiments on fields and grasslands, that a simultaneous reduction of total porosity and macropore volume reduces the gas and fluid conductivity. Radford et al. (2000) indicate that the unsaturated hydraulic conductivity of a clay Vertisol $(V R)$ in wet soil conditions decreased after soil compaction during harvester traffic with 0,10 and $12 \mathrm{Mg}$ axle loads and was greater at 10 $\mathrm{cm}$ depth than at the soil surface. Yavuzcan et al. (2005) found that field traffic with a wheel load of $11 \mathrm{Mg}$ caused a significant reduction in the air permeability of arable loess soil (Regosol, $R G$ ) down to $40 \mathrm{~cm}$ depth only after a single pass. Furthermore, water and air conductivity depend not only on macropore volume but also on connectivity. Wheeling on the grassland causes a load-dependent decrease of soil volume and shearing processes that cause changes in pore continuity. Pagliai et al. (2003) found a highly significant linear correlation between hydraulic conductivity and elongated continuous pores. After one and four passes in the same track of rubber-tracked tractors and wheeled tractors of medium power on a compacted clay soil (Vertic Cambisol, CMvr), $\mathrm{k}_{\mathrm{s}}$ decreased in the 0-10 cm layer. After four passes with the rubber-wheeled tractor, hydraulic conductivity was tremendously reduced, consistent with the presence of few if any elongated pores and the finding that the pores present were thin and not vertically continuous. Additionally, O'Sullivan et al. (1999 b) demonstrated that a decrease in pore continuity can occur at the same BD as a result of shearing.

Precompression stress $(P)$ and cohesion. Precompression stress is an important parameter in soil mechanics and is often used as a criterion for soil susceptibility to compaction. Soil cohesion is the tendency of the particles to stick to one another and reflects soil consistency and workability. Soil $\mathrm{P}$ increased with soil depth in the uncompacted area. $\mathrm{P}_{c}$ values of the 
uncompacted area were approximately $30 \mathrm{kPa}$ lower at 5 and $10 \mathrm{~cm}$ depth than at $20 \mathrm{~cm}$ depth, whereas cohesion was higher at 5 and $10 \mathrm{~cm}$ depth than at $20 \mathrm{~cm}$ depth (Figs 6 and 7). $\mathrm{P}$ and soil cohesion were both lower in the uncompacted area than in the compacted area. The increase in $\mathrm{P}$ exceeded $60 \mathrm{kPa}$ at $5 \mathrm{~cm}$ depth, whereas at $10 \mathrm{~cm}$ depth, the change exceeded $30 \mathrm{kPa}$. At $5 \mathrm{~cm}$ depth, the increase in $\mathrm{P}$ was significantly larger than at 10 and $20 \mathrm{~cm}$ depth. This difference may be caused by shear strength. The traffic caused soil compaction and shearing at $5 \mathrm{~cm}$ depth. Shearing causes disproportionately heavy soil compaction because of increased cohesion. The mean change in soil cohesion due to compaction was $10 \mathrm{kPa}$.

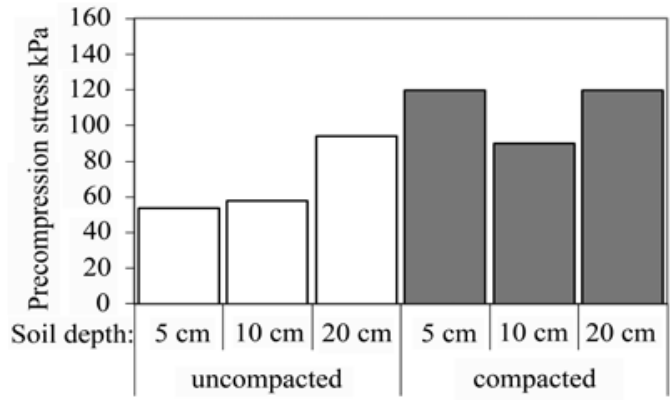

Figure 6. Soil precompression stress (P) (measured at $\mathrm{pF}=1.8$ ) depending on soil compaction and soil depth

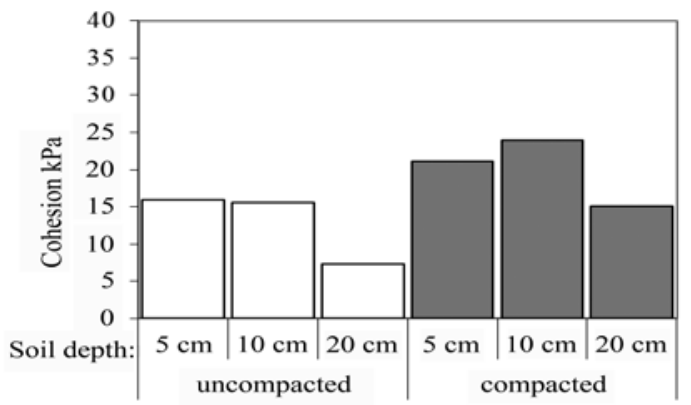

Figure 7. Soil cohesion (measured at $\mathrm{pF}=1.8$ ) depending on soil compaction and soil depth

We found pronounced changes in the soil stability parameters of $\mathrm{P}$ and cohesion due to soil compaction. These changes occurred because the machinery had a contact area pressure over 3.5 times higher than the soil's internal strength $\left(\mathrm{P}_{\mathrm{c}}\right)$, causing irreversible damage to the former soil structure. During soil deformation, soil particles are pushed closer to one another, leading to a higher soil $\mathrm{BD}$ with more contact points between soil particles. This higher BD leads to higher values of soil cohesion in the compacted area compared with the uncompacted area. Dörner and Horn (2009) reported that cohesion is higher in the mechanically strongly loaded plough pan than in the upper layers. Stahl et al. (2009) investigated the effect of wheeling with a manure tanker (contact area of 150 $\mathrm{kPa}$ ) on grassland under moist to wet soil conditions on soil stability and found that soil $\mathrm{P}_{\mathrm{c}}$ was higher in the wheel tracks. Precompression stress increased $27 \mathrm{kPa}$ at $10 \mathrm{~cm}$ depth and $17 \mathrm{kPa}$ at $20 \mathrm{~cm}$ depth.

\section{Conclusions}

Our field experiment shows that soil bulk density (BD), pore size distribution, air conductivity $\left(\mathrm{k}_{\mathrm{a}}\right)$ and saturated hydraulic conductivity $\left(\mathrm{k}_{\mathrm{s}}\right)$ were significantly affected by wheeling with pick-up machinery on intensively used grassland (cut for silage). During wheeling on the lucerne field, soil compression occurred in the wheel tracks:
1. Soil compaction increased soil BD at $5-10$ $\mathrm{cm}$ depth, air capacity (AC) values at 5 and $10 \mathrm{~cm}$ depth were lower in the compacted area than in the uncompacted area and plant-available water (PAW) values increased at $10-20 \mathrm{~cm}$ depth and decreased at $5 \mathrm{~cm}$ depth with soil compaction.

2. The decrease in $\mathrm{k}_{\mathrm{a}}$ and $\mathrm{k}_{\mathrm{s}}$ due to soil compaction was statistically significant at 5 and $10 \mathrm{~cm}$ depth. Because of the decreased soil volume and associated decrease in macroporosity, the saturated water and $\mathrm{k}_{\mathrm{a}}$ were reduced in the compacted area.

3. Soil precompression stress $\left(\mathrm{P}_{\mathrm{c}}\right)$ and soil cohesion were both lower in the uncompacted area than in the compacted area (statistically not approved).

Our results showed that wheeling affected the soil structure in the grassland.

\section{Acknowledgements}

This study was supported by Estonian Science Foundation grant No. 7622, Christian Albrecht University of Kiel and the German Environmental Foundation.

Received 14062012 Accepted 31122012

\section{References}

AG Bodenkunde. 2005. Bodenkundliche Kartieranleitung [Pedological Mapping] (5 $5^{\text {th }}$ ed.). Hannover, Germany, 438 p. (in German)

Cofie P., Koolen A. J., Perdok U. D. 2000. Measurement of stress-strain relationship of beech roots and calculation of the reinforcement effect of tree roots in soil-wheel systems. Soil and Tillage Research, 57 (1-2): 1-12 http://dx.doi.org/10.1016/S0167-1987(00)00126-4

Douglas J. T., Crawford C. E. 1998. Soil compaction effects on utilization of nitrogen from livestock slurry applied to grassland. Grass and Forage Science, 53: 31-40 http://dx.doi.org/10.1046/j.1365-2494.1998.00101.x

Dörner J., Horn R. 2009. Direction-dependent behaviour of hydraulic and mechanical properties in structured soils under conventional and conservation tillage. Soil and Tillage Research. 102 (2): 225-232

http://dx.doi.org/10.1016/j.still.2008.07.004

DVWK (Deutscher Verband für Wasserwirtschaft und Kulturbau e.V.). 1995. Gefügestabilität ackerbaulich genutzter Mineralböden: Teil I. Mechanische Belastbarkeit. Merkblätter zur Wasserwirtschaft, 234: p. 1-5 (in German)

DVWK (Deutscher Verband für Wasserwirtschaft und Kulturbau e.V.). 1997. Gefügestabilität ackerbaulich genutzter Mineralböden: Teil II. Auflastabhängige Veränderung von bodenphysikalischen Kennwerten. Merkblätter zur Wasserwirtschaft, 235: p. 1-4 (in German)

Frame J., Merrilees D. W. 1996. The effect of tractor wheel passes on herbage production from diploid and tetraploid rvegrass swards. Grass and Forage Science. 51: 13-20 http://dx.doi.org/10.1111/j.1365-2494.1996.tb02033.x

Frost J. P. 1988. Effects on crop yields of machinery traffic and soil loosening. Part 1. Effects on grass yield of traffic frequency and date of loosening. Journal of Agricultural Engineering Research. 39: 301-312 http://dx.doi.org/10.1016/0021-8634(88)90151-5

Glab T. 2008. Effects of tractor wheeling on root morphology and yield of lucerne (Medicago sativa L.). Grass and Forage Science, 63: 398-406 http://dx.doi.org/10.1111/j.1365-2494.2008.00647.x

Hammel K. 1993. Spannungsverteilung und Bodenverdichtung unter profilierten Reifen am Beispiel zweier Böden unter Grünland: doctoral thesis. Universität Hohenheim, 144 p. (in German)

Hartge K. H., Horn R. 2009. Die physikalische Untersuchung von Böden ( $4^{\text {th }}$ ed.). Stuttgard, Germany, 178 p. (in German) 
Horn R., Rostek J. 2000. Subsoil compaction processes - state of knowledge / Horn R. et al. (eds). Subsoil compaction - distribution, processes and consequences. Advances in Geoecology, 32: 44-55

Horn R., Way T., Rostek J. 2003. Effect of repeated tractor wheeling on stress/strain properties and consequences on physical properties in structured arable soils. Soil and Tillage Research. 73 (1-2): 101-106 http://dx.doi.org/10.1016/S0167-1987(03)00103-X

IUSS Working Group WRB. 2007. World reference base for soil resources 2006, first update 2007. World Soil Resources Reports No. 103, FAO. Rome, Italy, p. 115

Jorajuria D., L. Draghi L. 1997. The distribution of soil compaction with depth and the response of a perennial forage crop. Journal of Agricultural Engineering Research, 66: 261-265 http://dx.doi.org/10.1006/jaer.1996.0141

Koppi A. J., Douglas J. T., Moran C. J. 1992. An image analysis evaluation of soil compaction in grassland. European Journal of Soil Science, 43 (1): 15-25 http://dx.doi.org/10.1111/j.1365-2389.1992.tb00116.x

Lipiec J., Hatano R. 2003. Quantification of compaction effects on soil physical properties and cron growth. Geoderma. 116: 107-136 http://dx.doi.org/10.1016/S0016-7061(03)00097-1

Oldeman L. R., Hakkeling R. T. A., Sombroek W. G. 1991. World map of the status of human-induced soil degradation. Wageningen, Netherlands, Nairobi, Kenya, 34 p.

O'Sullivan M. F., Henshall J. K., Dickson J. W. 1999 (a). A simplified method for estimating soil compaction. Soil and Tillage Research. 49 (4): 325-335 http://dx.doi.org/10.1016/S0167-1987(98)00187-1

O'Sullivan M. F., Robertson E. A. G., Henshall J. K. 1999 (b). Shear effects on gas transport in soil. Soil and Tillage Research. 50 (1): 73-83 http://dx.doi.org/10.1016/S0167-1987(98)00195-0

Pagliai M., Marsili A., Servadio P., Vignozzi N., Pellegrini S. 2003. Changes in some physical properties of a clay soil in Central Italy following the passage of rubber tracked and wheeled tractors of medium power. Soil and Tillage Research. 73 (1-2): 119-129 http://dx.doi.org/10.1016/S0167-1987(03)00105-3

Radford B. J., Bridge B. J., Davis R. J., McGarry D., PillaiMcGarry U. P., Rickman J. F., Walsh P. A., Yule D. F. 2000.
Changes in the properties of a Vertisol and responses of wheat after compaction with harvester traffic. Soil and Tillage Research. 54 (3-4): 155-170

http://dx.doi.org/10.1016/S0167-1987(00)00091-X

Reintam E., Kuht J., Trükmann K., Leal Filho W. 2006. Effect of annual lupines growing on compacted sandy loam Stagnic Luvisol. Archives of Agronomy and Soil Science. 52 (2): 171-181 http://dx.doi.org/10.1080/03650340600581885

Reintam E., Trükmann K., Kuht J., Nugis E., Edesi L., Astover A., Noormets M., Kauer K., Krebstein K., Rannik K. 2009. Soil compaction effects on soil bulk density and penetration resistance and growth of spring barley (Hordeum vulgare L.). Acta Agriculturae Scandinavica, Section B: Soil and Plant Science. 59 (3): 265-272 http://dx.doi.org/10.1080/09064710802030070

Schäfer-Landefeld L., Brandhuber R., Fenner S., Koch H. J., Stockfisch N. 2004. Effects of agricultural machinery with high axle load on soil properties of normally managed fields. Soil and Tillage Research. 75 (1): 75-86 http://dx.doi.org/10.1016/S0167-1987(03)00154-5

Stahl H., Marschall K., Götze H., Freytag A. 2009. Bodendruck im Grünland. Schriftenreihe des Landesamtes für Umwelt, Landwirtschaft und Geologie des Freistaates Sachsen, 3: 1-60 (in German)

Statistikaamet. 2012 [Statistics Estonia]. <http://www.stat. ee/34226> [accessed 1503 2012]

Trükmann K. 2011. Quantifizierung der Stabilisierungseffekte von Pflanzenwurzeln als Möglichkeit zur Reduzierung der mechanischen Bodendeformationen in Grünland: doctoral thesis. Christian-Albrechts-Universität zu Kiel. $<$ http://eldiss.uni-kiel.de/macau/receive/dissertation diss_00006942> [accessed 1503 2012] (in German)

Vossbrink J., Horn R. 2004. Modern forestry vehicles and their impact on soil physical properties. European Journal of Forest Research. 123: 259-267 http://dx.doi.org/10.1007/s10342-004-0040-8

Yavuzcan H. G., Matthies D., Auernhammer H. 2005. Vulnerability of Bavarian silty loam soil to compaction under heavy wheel traffic: impacts of tillage method and soil water content. Soil and Tillage Research. 84 (2): 200-215 http://dx.doi.org/10.1016/j.still.2004.11.003

ISSN 1392-3196

Zemdirbyste-Agriculture, vol. 100, No. 1 (2013), p. 33-38

UDK 631.431.73:633.2.033 / DOI 10.13080/z-a.2013.100.005

\title{
Rudžemio suslègimas Estijos pievose
}

\author{
K. Krebstein ${ }^{1}$, K. von Janowsky², E. Reintam ${ }^{1}$, R. Horn ${ }^{3}$, J. Leeduks ${ }^{1}$, J. Kuht ${ }^{1}$ \\ ${ }^{1}$ Estijos gyvybės mokslų universiteto Žemès ūkio ir aplinkos mokslų institutas \\ ${ }^{2}$ Higienos ir aplinkos institutas, Vokietija \\ ${ }^{3}$ Kylio Christiano Albrechto universitetas, Vokietija
}

\section{Santrauka}

Tiriant dirvožemio suslègimą, daugiau dèmesio skiriama ariamai žemei nei ganykloms. Tyrimo tikslas - ištirti žemès ūkio mašinų poveikị fizinėms bei mechaninèms dirvožemio, kuriame buvo auginta ir intensyviai pjauta mėlynžiedè liucerna (Medicago sativa L.), savybèms. Lauko bandymas vykdytas Pietų Estijoje, netoli Tartu, antrujų metų naudojimo žolyne, kurio pagrindą sudare liucernos, karbonatingame rudžemyje (RDk), smėlingame priemolyje. Po trečios pjūties silosui dirvožemio savybès vertintos ratų vėžèse (suslègta) ir tarpuvèžèse (nesuslègta). Tyrimo rezultatai parodè, kad dirvožemio suslègimas traktoriaus ratais smarkiai paveikè jo struktūrą. Suslègimas dirvožemio tankị $5 \mathrm{~cm}$ gylyje padidino $0,19 \mathrm{~g} \mathrm{~cm}^{-3}, \mathrm{o} 10 \mathrm{~cm}$ gylyje $-0,14 \mathrm{~g} \mathrm{~cm}^{-3}$. Dirvožemio suslègimas taip pat paveikè poru pasiskirstymą: suslègto dirvožemio poringumas 5 ir $10 \mathrm{~cm}$ gylyje buvo gerokai (daugiau nei $10 \mathrm{~cm}^{3}$ $\mathrm{cm}^{-3}$ ) mažesnis, o augalų pasisavinama drègmé padidèjo 10 ir $20 \mathrm{~cm}$ gylyje, bet sumažèjo $5 \mathrm{~cm}$ gylyje. Dirvožemio laidumas orui ir prisotintas hidraulinis laidumas smarkiai sumažejo 5 ir $10 \mathrm{~cm}$ gylyje. Dirvožemio stresas prieš suslègimą buvo mažesnis nesuslègtame plote: suslègimas dirvožemio stresą $5 \mathrm{~cm}$ gylyje padidino $60 \mathrm{kPa}, 10 \mathrm{~cm}$ gylyje - $30 \mathrm{kPa}$. Dirvožemio rišlumas buvo didesnis suslègtame plote, palyginus su nesuslègtu (vidutinis skirtumas $-10 \mathrm{kPa}$ ). Tyrimo rezultatai parodè, kad dirvožemio suslègimas ganyklose yra problema.

Reikšminiai žodžiai: dirvožemio suslègimas, ganykla, hidraulinis laidumas, oro laidumas, rišlumas, suslègimo stresas, tankis. 